\title{
От Уполномоченного императорского российского правительства в Монголии И. Я. Коростовца до Уполномоченного НКИД РСФСР в Монголии О. И. Макстенека: к 100-летию российско-монгольских дипломатических отношений
}

\author{
Леонид Владимирович Курас ${ }^{1}$, Базар Догсонович Цыбенов ${ }^{2}$
}

${ }^{1}$ Институт монголоведения, буддологии и тибетологии СО РАН (д. 6, ул. Сахьяновой, 670047 Улан-Удэ, Российская Федерация) доктор исторических наук, главный научный сотрудник

(iD) 0000-0003-4507-249X. E-mail: kuraslv@yandex.ru

${ }^{2}$ Институт монголоведения, буддологии и тибетологии СО РАН (д. 6, ул. Сахьяновой, 670047 Улан-Удэ, Российская Федерация)

кандидат исторических наук, старший научный сотрудник

(iD) 0000-0002-0404-7207. E-mail: bazar75@mail.ru

(C) КалмНЦ РАН, 2021

(С) Курас Л. В., Цыбенов Б. Д., 2021

Аннотация. Актуальной проблемой современного монголоведения продолжает оставаться определение места и роли российско-монгольских дипломатических отношений в укреплении монгольской государственности в первой четверти XX в. Ход революционного движения во Внутренней Азии и в целом вся социальнополитическая история современной Монголии тесно связаны с усилиями российской дипломатии, именами ряда дипломатов, немало сделавших для усиления монгольского направления восточной политики российского государства. Цель статьи - исследовать деятельность российских дипломатов - уполномоченного императорского российского правительства в Монголии И. Я. Коростовца и уполномоченного Народного комиссариата по иностранным делам РСФСР в Монголии О. И. Макстенека. Для ее достижения были поставлены следующие задачи: осветить историографию вопроса, изучить российско-монгольское Соглашение 1912 г., дать характеристику событий во Внешней Монголии в 1917-1920 гг., провести анализ отчета О. И. Макстенека как источника по истории Монгольской революции 1921 г. и советско-китайским отношениям. Bblвoдbl. Уполномоченный императорского российского правительства в Монголии И. Я. Коростовец и уполномоченный Народного комиссариата по иностранным делам РСФСР в Монголии О. И. Макстенек сыграли большую роль в формировании региональной системы международных отношений в Байкальском регионе. Российско-монгольское соглашение 1912 г., во многом подготовленное благодаря 
усилиям И. Я. Коростовца, по сути, сделало Монголию субъектом международного права и положило начало пути монголов к обретению фактической и юридической независимости от Китая. Отчет О. И. Макстенека показывает колоссальную работу, проделанную им в ходе подготовки Монгольской революции 1921 г. Помимо приема и отправки монгольских революционеров в Советскую Россию, подготовки первого съезда революционной монгольской партии и формирования отрядов монгольской народнореволюционной армии, он вел переговоры с китайскими властями Урги и Маймачена и тем самым фактически начал дипломатическую проработку будущего ввода советских войск на территорию Монголии.

Ключевые слова: российская дипломатия, Монголия, И. Я. Коростовец, российскомонгольское соглашение 1912 г., О. И. Макстенек, Монгольская революция 1921 г.

Благодарность. Исследование проведено в рамках проекта РФФИ - Министерства образования, культуры и науки (Монголия), № 19-59-44004 «Монгольская революция 1921 г. в зеркале транснациональной истории монгольского мира» (к 100-летию Монгольской революции 1921 г.) (номер госрегистрации: АААА-А20-120021490062-5). Для цитирования: Курас Л. В., Цыбенов Б. Д. От Уполномоченного императорского российского правительства в Монголии И. Я. Коростовца до Уполномоченного НКИД РСФСР в Монголии О. И. Макстенека: к 100-летию российско-монгольских дипломатических отношений // Монголоведение. 2021. Т. 13. № 2. C. 351-365. DOI: 10.22162/2500-1523-2021-2-351-365

\title{
From Imperial Russia's Plenipotentiary in Mongolia I. Ya. Korostovets to Representative of RSFSR People's Commissariat of Foreign Affairs O. I. Makstenek: Celebrating the $\mathbf{1 0 0}^{\text {th }}$ Anniversary of Russia-Mongolia Diplomatic Relations
}

\author{
Leonid V. Kuras ${ }^{1}$, Bazar D. Tsybenov ${ }^{2}$
}

${ }^{1}$ Institute for Mongolian, Buddhist and Tibetan Studies, Siberian Branch of the RAS (6, Sakhyanova St., 670047 Ulan-Ude, Russian Federation)

Dr. Sc. (History), Chief Research Associate

(iD) 0000-0003-4507-249X. E-mail: kuraslv@yandex.ru

${ }^{2}$ Institute for Mongolian, Buddhist and Tibetan Studies, Siberian Branch of the RAS (6, Sakhyanova St., 670047 Ulan-Ude, Russian Federation)

Cand. Sc. (History), Senior Research Associate

(iD)0000-0002-0404-7207. E-mail: bazar75@mail.ru

(C) KalmSC RAS, 2021

(C) Kuras L. V., Tsybenov B. D., 2021

Abstract. Introduction. An urgent issue of Mongolian studies today is the role of RussianMongolian diplomatic relations in promoting the statehood of Mongolia in the first quarter of the twentieth century. The revolutionalry movement in Inner Asia, in particular, and the social-political history of modern Mongolia, in general, are closely associated with the efforts of Russian diplomacy and, especially, with a number of diplomats who greatly contributed 
to the promotion of Mongolian direction of the Russian politics in the East. The aim of the present article is the study of the activities of Russian diplomats, namely I. Ya. Korostovets, the Plenipotentiary of the Imperial Russian Government in Mongolia, and O. I. Makstenek, the Representative of the People's Commissariat of Foreign Affairs of the RSFSR in Mongolia. Accordingly, the research has been conducted along the following lines: $i$ ) history of the issue, ii) examination of 1912 Russian-Mongolian agreement, iii) description of the events in Outer Mongolia between 1917 and 1920, and iv) analysis of Makstenek's report as a source on the history of Mongolian Revolution of 1921 and the Soviet-Chinese relations. Conclusions. Both Korostovets, on behalf of the Russian Imperial Government, and Makstenek, on behalf of the RSFSR, played a significant role in establishing the regional system of international relations in the Baikal region. The 1912 Russian-Mongolian Agreement, which was in fact the result of Korostovets' efforts, was instrumental in promoting Mongolia as a subject of international law and in initiating the movement of Mongolians to their de facto and de jure independence from China. Makstenek's report shows much effort the Soviet diplomat took in preparing the Mongolian Revolution of 1921. Besides receiving and delegating Mongolian revolutionaries to Soviet Russia, taking an active part in preparations to the First Congress of the Mongolian People's Revolutionary Party and in the formation of military detachments of Mongolian People's Revolutionary Army, Makstenek conducted negotiations with the Chinese authorities in Urga and Maimachen, i.e. in fact initiated the diplomatic proceedings designed to prepare the presence of Soviet troops in Mongolia.

Keywords: Russian diplomacy, Mongolia, I. Ya. Korostovets, Russian-Mongolian Agreement of 1912, O. I. Makstenek, Mongolian Revolution of 1921

Acknowledgements. The reported study was funded by RFBR and Ministry of Education, Culture and Science of Mongolia, no. 19-59-44004 'The Mongolian Revolution of 1921 in the Mirror of Transnational History of the Mongolian World: Celebrating the $100^{\text {th }}$ Anniversary of the Mongolian Revolution of 1921' (state reg. no. AAAA-A20-120021490062-5).

For citation: Kuras L. V., Tsybenov B. D. From Imperial Russia's Plenipotentiary in Mongolia I. Ya. Korostovets to Representative of RSFSR People's Commissariat of Foreign Affairs O. I. Makstenek: Celebrating the $100^{\text {th }}$ Anniversary of Russia-Mongolia Diplomatic Relations. Mongolian Studies (Elista). 2021; 13(2): 351-365. (In Russ.). DOI: 10.22162/2500-1523-2021-2-351-365

\section{Введение}

В 2021 г. монгольская и российская общественность отмечают замечательные юбилеи в истории современной Монголии: 110 лет Монгольской революции 1911 г. и 100 лет Монгольской народной революции 1921 г. Между этими историческими событиями пролегло 10 лет, но это звенья одной цепи, непосредственное отношение к которым имели сначала Российская империя, а затем - Советская Россия.

Изучая историю революционного движения любой страны, исследователи традиционно заостряют внимание на личностях вождей революции, ее движущих силах, а также на армии, призванной защищать завоевания революции. Однако не менее, а может быть, и более важным является факт признания (или не признания) международным сообществом результатов революции, возможности инкорпорации молодого государства в систему международных отношений, которая образуется и существует в рамках отдельных регионов. Исходя из этого посыла, мы хотим обратить внимание на столетний юбилей российско-монгольских дипломатических отношений и в качестве объекта 
нашего исследования избрали исторические личности российских дипломатов: Ивана Яковлевича Коростовца ${ }^{1}$ - Уполномоченного Российской империи в Монголии (1912-1913 гг.) и Отто Ивановича Макстенека ${ }^{2}$ - Уполномоченного Народного комиссариата по иностранным делам (далее - НКИД) Советской России в Монголии (1920-1921 гг.).

\section{Материалы и методы}

В написании работы авторы использовали уникальные документы по личности первого Уполномоченного НКИД РСФСР в Монголии О. И. Макстенека. Они находятся на хранении в Центральном архиве внешних сношений Монголии и Государственном архиве Российской Федерации. Исследователи обращались также к опубликованным архивным материалам в сборниках документов «Монголия в документах Коминтерна (1919-1934). Ч. 1» [Монголия 2012], «Российско-монгольское военное сотрудничество (1911-1946)» [РМВС 2008], «Международные

${ }^{1}$ Коростовец Иван Яковлевич (25.08.1862, Полтавская губ., Российская империя 01.01.1933, Париж) - российский дипломат, востоковед. Тайный советник. Окончил Императорский Александровский лицей (1884), принят на службу в Азиатский департамент МИД России. Второй драгоман (1894-1890), второй секретарь (1890-1894) российской дипломатической миссии в Пекине, секретарь миссий в Рио-де-Жанейро (1894-1896) и Лиссабоне (1896-1899), чиновник по дипломатической части при Главном начальнике Квантунской области в Порт-Артуре (1899-1902), в августе-сентябре 1901 г. временно управлял делами консульства России в Тяньцзине. С 1902 г. — генеральный консул в Бушире (Персия). В 1905 г. участвовал в работе российской делегации при заключении Портсмутского мира с Японией, был, наряду с К. Д. Набоковым, секретарем российского уполномоченного С. Ю. Витте. С марта 1908 г. вице-директор 1-го Департамента МИД. В 1908-1911 гг. - чрезвычайный посланник и полномочный министр Российской империи в Китае. В 1912 г. возглавил русскую дипломатическую миссию в Урге; был уполномочен правительством России вести переговоры с монгольским правительством. 21 октября (3 ноября) 1912 г. подписал в Урге русско-монгольское соглашение, признававшее автономию Внешней Монголии и предоставлявшее российским подданным в Монголии ряд привилегий (беспошлинная торговля, свободное проживание и передвижение в Монголии, совершение любых коммерческих операций и др.). Тем самым, Россия признала независимость монгольского государства. В 1913-1915 гг. он - чрезвычайный посланник и полномочный министр Российской империи в Персии, с 1916 г. — председатель Правления Учетно-Ссудного Банка Персии. В 1915-1917 гг. - член Совета МИД России. После Октябрьской революции 1917 г. эмигрировал, проживал в Финляндии, Пекине. Скончался в Париже [Батсайхан 2013а; Батсайхан 2013б; Батсайхан 2016; Батсайхан 2021].

${ }^{2}$ Макстенек Отто Иванович (1874, Латвия, Валкский уезд - 29 июня 1939 г. расстрелян). Латыш, из рабочих, образование низшее, член ВКП(б) с 1904 г., исключен в 1928 г., восстановлен в 1929 г., активный участник революции 1905-1907 гг., политкаторжанин, ссыльнопоселенец, участник гражданской войны в Восточной Сибири, первый уполномоченный Наркомата по иностранным делам РСФСР в Монголии, награжден орденом Красного Знамени (Монголия), член Общества бывших политкаторжан и ссыльнопоселенцев (исключен в 1928 г.). Последнее место работы - директор детского дома, санаторий им. ВЦИК в Солнечногорском районе. 19 февраля 1938 г. арестован как активный участник контрреволюционной группы латышей под руководством Яна Рудзутака. 20 августа 1938 г. расстрелян. Место смерти - Московская обл., Бутово. Место захоронения - Московская обл. В 1959 г. реабилитирован [ГА РФ. Ф.-10035. Оп. 1. Д. П-61825]. 


\section{Источниковедение}

отношения в эпоху империализма: документы из архивов царского и Временного правительств 1878-1917 гг.» [Международные отношения 1933].

Деятельность российского дипломата И. Я. Коростовца была прослежена на основе опубликованных им работ: «Девять месяцев в Монголии. Дневник русского уполномоченного в Монголии. Август 1912 - май 1913 г.» [Коростовец 2009], «От Чингисхана до Советской республики (Краткая история Монголии с особым учетом новейшего времени)» [Коростовец 2004].

Авторами рассмотрены публикации монгольского историка О. Батсайхана, а также работы О. Бакич, В. Г. Дацышена. В изучении ряда исторических событий, связанных с российско-монгольскими отношениями в первой четверти XX в., авторы привлекали и некоторые свои ранее опубликованные работы. Основным методом, примененным в написании настоящей статьи, является сравнительно-исторический метод. С его помощью были проанализированы общие и особенные моменты в деятельности российских дипломатов, сделан вывод об их значении в создании региональной системы международных отношений в Центральной Азии. В работе нашел также применение и типологический метод, позволивший авторам грамотно ориентироваться в типах государственности и правления в Байкальском регионе в сложный революционный период. Авторы прибегали и к источниковедческим методам, связанным с выявлением, описанием и анализом архивных материалов.

\section{От Коростовца до Макстенека: российская дипломатия в Монголии в первой четверти XX в.}

Уполномоченный императорского российского правительства в Монголии И. Я. Коростовец

К историографии вопроса

Современные историки-востоковеды уделяют пристальное внимание итогам Синьхайской революции в Китае, одним из которых стало восстановление государственности северной национальной окраины - Внешней Монголии. Изучение этой проблемы, как отмечают российские исследователи, невозможно без обращения к личности выдающегося российского дипломата И. Я. Коростовца [Курас 2016а]. Но пальма первенства в этом вопросе заслуженно принадлежит монгольской историографии. Ценные данные о дипломате из Архива внешней политики Российской империи были введены в научный оборот монгольским историком О. Батсайханом. Упор в своем изучении он делал на период пребывания И. Я. Коростовца во Внешней Монголии. Дипломат хорошо знал ситуацию в регионе, в Китае он находился с 1908 г. Зная его личные качества и таланты, российское правительство направило в 1912 г. Коростовца в Ургу для налаживания тесных контактов с правительством Богдо-гэгэна. Заслуга О. Батсайхана состоит в том, что им впервые детально изучен весь период нахождения И. Я. Коростовца в Монголии [Батсайхан 2013а; Батсайхан 2013б; Батсайхан 2013в; Батсайхан 2016; Батсайхан 2021].

Долгое время имя И. Я. Коростовца находилось в забвении, что было обусловлено его эмиграцией после Октябрьской революции 1917 г. Интерес к деятельности дипломата и ученого возник лишь в начале 2000-х гг. благодаря усилиям академика Б. В. Базарова, профессора В. Ц. Ганжурова и профессора О. Батсайхана, которые опубликовали многолетнее исследование И. Я. Коростовца по истории Монголии [Коростовец 2004]. 
Дневник дипломата «Девять месяцев в Монголии. Дневник русского уполномоченного в Монголии. Август 1912 - май 1913 г.» был опубликован на русском языке в 2009 г. и на монгольском языке в 2010 г. [Коростовец 2009].

Кроме того, в 2013 г. в Улан-Баторе состоялась научная конференция, предметом которой стала жизнь и деятельность И. Я. Коростовца [Батсайхан 2013а; Лиштованный 2013; Курас, Цыбенов 2013; Бакич 2013].

Российско-монгольское соглашение 1912 г.

Падение империи Цин способствовало тому, что Внешняя Монголия провозгласила свою независимость. Это стало началом новой эпохи в истории монголов. 29 декабря 1911 г. на престол императора Монголии был возведен VIII Богдо Джебцзундамба-хутухта. Российская империя, в свою очередь, была заинтересована в усилении своего влияния во Внешней Монголии. В то же время быстрыми темпами увеличивала свое влияние во Внутренней Азии и Япония.

$\mathrm{B}$ начале XX в. между Россией и Японией был заключен ряд секретных договоров. Отныне Япония, активно продвигающаяся в западном направлении, имела интересы в Маньчжурии, а Россия — во Внешней Монголии.

О демонстрации присутствия России в указанном регионе ярко свидетельствует нота, направленная китайскому правительству в марте 1912 г.: «В случае отправления войск Китаем из Хэйлунцзяна и ввода их в Монголию, Россия не останется безучастной» [Международные отношения 1933: 227].

Последующие дипломатические шаги России в 1912-1915 гг. показали, что она твердо руководствовалась ранее принятыми положениями. В этой связи, несомненно, выделяется Соглашение России о дружбе с Монголией, заложившей фундамент будущих дипломатических отношений между нашими странами. Благодаря оперативным и грамотным действиям И. Я. Коростовца Соглашение сделало Монголию субъектом международного права и в неизменном виде стало сегментом Кяхтинского Соглашения 1915 г. О. Батсайхан выделяет четыре основных момента монгольской государственности: во-первых, назначение правителя Монголии и создание монгольского правительства; во-вторых, формирование национальной армии; в-третьих, появление черт суверенного государства; в-четвертых, вывод китайских войск, запрет на допуск к монгольской территории китайских солдат и крестьян-переселенцев [Батсайхан 2021: 21-22].

Одним из активных сторонников России был монгольский чиновник Ханда-ван ${ }^{3}$. Именно ему Богдо-гэгэн поручил передать свои поздравления российскому консулу по случаю заключения российско-монгольского дружественного Договора. Правитель России также не остался в стороне и собственноручно написал в телеграмме: «Выражаю свою благодарность Коростовцу. Милостью царя» [Батсайхан 2021: 22].

Богдо-гэгэн высоко оценил деятельность И. Я. Коростовца. В мае 1913 г. ему было присвоено звание «циньвана» (князь первой степени), также он был награжден орденом Вачира — высшей наградой Внешней Монголии в ту пору.

\footnotetext{
${ }^{3}$ М. Ханддорж - министр иностранных дел в правительстве Богдо-хана. По возвращении из Санкт-Петербурга зимой 1912 г., где он был награжден Орденом Анны I степени, а также Орденами Станислава I и II степени, он предложил Богдо-хану создать собственную наградную систему по образцу российской. По его инициативе в Урге в 1912 г. открылась первая школа переводчиков русского языка.
} 


\section{Источниковедение}

Российско-монгольский договор 1912 г. привлекал внимание современников, в частности, особенно высоко его оценивали в дипломатических кругах. Например, Б. Э. Нольде, известный российский дипломат и юрист, в своей работе «Далекое и близкое» отмечал: «Создание Монголии - одно из крупных дипломатических достижений императорской России. ... в первых рядах этой школы стояли перед войной И. Я. Коростовец и покойный начальник дальневосточного отдела Г. А. Козаков. Им вместе принадлежит честь осуществления того крупного исторического дела... Договор И. Я. Коростовца сыграл решающую роль в процессе образования Монголии» [Нольде 1930: 70-77].

3 сентября 2014 г. в Улан-Баторе, в рамках рабочего визита Президента России В. В. Путина в Монголию, был открыт памятник И. Я. Коростовцу, сыгравшему определяющую роль в обеспечении независимости Монголии.

Следует подчеркнуть, что российско-монгольское Соглашение и российско-китайская Декларация - это образец подготовки и осуществления дипломатической миссии, и потому в 1914 г. этот документ был опубликован в сборнике дипломатических документов. Сборник был специально посвящен монгольскому вопросу, причем, кроме собственно Соглашения и протокола, в сборник вошла дипломатическая переписка, предшествовавшая заключению русско-монгольского Соглашения, дипломатическая переписка, предшествовавшая подписанию русско-китайской Декларации по монгольскому вопросу, сама русско-китайская Декларация и ноты по монгольскому вопросу, а также извещение монгольского правительства о подписании русско-китайского Соглашения по монгольскому вопросу. То есть это была публикация, которая предвосхитила идею В. И. Ленина, выступавшего против тайной дипломатии и тайных договоров [Ленин 1969: 232] и требовавшего скорейшего опубликования тайных договоров царского и Временного правительств.

\section{Уполномоченный НКИД РСФСР в Монголии О. И. Макстенек}

Внешняя Монголия в 1917-1920 г2.

Наступил победный Октябрь 1917 г. Новая власть начала подготовку и публикацию тайных договоров, заключенных царской Россией с другими империалистическими державами, в надежде на скорую мировую революцию. Но начавшаяся в России гражданская война и иностранная военная интервенция в страну перечеркнули эти планы. В этих условиях Китайская Республика и Внешняя Монголия не признали Советское правительство, а китайское руководство посчитало возможным дезавуировать условия Кяхтинского Соглашения и летом 1918 г. ввело в столицу Внешней Монголии китайский батальон.

Положение усугубил панмонгольский съезд, состоявшийся в Чите в конце февраля 1919 г. по инициативе атамана Г. С. Семенова. Делегаты съезда, представлявшие бурят Забайкалья и монголов Барги и Внутренней Монголии, провозгласили создание независимого панмонгольского государства. Главой был назначен Нейсе-гэгэн, уроженец Внутренней Монголии [Курас 2011: 255-262].

Внешняя Монголия отказалась принять участие в политической авантюре, и «Даурское правительство» пригрозило отправкой во Внешнюю Монголию военной экспедиции. Китайское правительство рассматривало вопрос о вводе китайских войск во Внешнюю Монголию. Первые китайские солдаты появились в Урге в начале июля 1919 г. События развивались стремительно: в середине 
июля указом президента Китайской Республики была создана новая должность по урегулированию ситуации на северо-западной границе, и появилось специальное учреждение «Бюро по заведованию делами пограничной обороны» [Дацышен 2014].

В китайском правительстве выдвигались предложения об усилении северо-западных рубежей страны путем формирования новых воинских контингентов в этом регионе. В своем решении китайские политические деятели руководствовались шатким положением Омского правительства, усилением войск атамана Г. С. Семенова на границе с Внешней Монголией, боязнью проникновения на китайскую территорию большевистских идей.

К середине 1919 г. был арестован Богдо-гэгэн, монгольская автономия упразднена, а Внешняя Монголия вновь становится китайской провинцией, в которой установлен жестокий оккупационный режим. Это привело к политическому кризису монгольского общества и возникновению реальной угрозы на границе Советской России. В этих условиях политические круги Монголии раскололись на три части:

1) прокитайская группа, направившая депутацию в Пекин с просьбой смягчить оккупационный режим;

2) прозападная группа пыталась заигрывать с Японией и Северо-Американскими Соединенными Штатами, которые не проявляли интереса к «монгольским делам»;

3) пророссийская группа, представленная двумя подпольными, антикитайскими кружками в Урге: «Консульский холм» (Д. Бодо, Х. Чойбалсан) и «Восточное хурэ» (С. Данзан, Д. Догсом, Д. Сухэ-Батор). Это были новые общественные силы Монголии, которые изначально сделали ставку на Советскую Россию. Именно в этот период по времени совпало национально-освободительное движение монгольского народа и поворот политического вектора Коминтерна на восток [Монголия 2012: 34-36].

Знаменательным событием явился приезд в Ургу в марте 1920 г. большевика Н. Г. Буртмана. Он устанавливает связи с местной русской колонией и особенно с революционерами. Н. Г. Буртман не обошел вниманием и два подпольных кружка, основанных монгольскими деятелями. Он сумел довести до них основные цели и задачи, стоящие перед большевиками.

В том же мае 1920 г. состоялся приезд в Ургу члена РКП(б) С. С. Борисова, также вызвавший интерес революционно настроенной части монгольского общества. Очевидно, поездка в Монголию сыграла большую роль в карьерном росте С. С. Борисова. Вскоре он становится главой монголо-тибетского отдела секции восточных народов Сибирского бюро Центрального комитета РКП(б). Монгольские революционеры, находящиеся в подполье, все более отчетливо осознают важность установления связей именно с Советской Россией. Северный сосед со времен деятельности И. Я. Коростовца в 1912-1913 гг. воспринимался монголами как стратегический партнер, имеющий реальные шансы изменить будущее Внешней Монголии. На повестке дня стоял вопрос об отправке монгольской делегации в Россию. 25 июня 1920 г. прошло Учредительное собрание Монгольской народной партии. Революционеры решились на радикальный 


\section{Источниковедение}

шаг — отправку специально выбранных делегатов в РСФСР. Учитывая сложную обстановку на российско-монгольской границе, планировалось переправить делегатов тремя отдельными группами. Впоследствии эти семь делегатов (Д. Бодо, С. Данзан, Д. Сухэ-Батор, Х. Чойбалсан, Д. Чагдаржав, Д. Догсом, Д. Лосол) вошли в новейшую историю Монголии под названием «монгольская семерка» [Курас, Цыбенов 2020: 83].

Отчет О. И. Макстенека как источник по истории Монгольской револющии 1921 г. и советско-китайских отношений

Прибытие в Троицкосавск О. И. Макстенека, уполномоченного НКИД РСФСР в Монголии, состоялось в июне 1920 г. Большевика старой закалки (вступил в РКП(б) в 1904 г.) [ГА РФ. Ф. 10035. Оп. 1. Д. П-61825. Л. 1-3] не смутила реакция китайских чиновников приграничного Маймачена, воспрепятствовавших его продвижению в Ургу. Этот период из жизни советского дипломата получил высокую оценку в отечественной историографии [Курас, Цыбенов 2020: 84-88].

Но самый важный документ, заверенной копией которого мы располагаем, хранится в Центральном архиве внешних сношений Монголии. Его название «Итоги деятельности уполномоченного Наркоминдел в Монголии О. И. Макстенека за время с 1-го июня 1920 г. по март 1921 г.» [ЦА ВСМ. Ф. 495. Оп. 152. Д. 9. Л. 45-57]. Этот документ мы полностью, без купюр, ввели в научный оборот [Хишигт, Курас, Цыбенов 2020: 308-315], что позволяет составить портрет Отто Ивановича Макстенека - дипломата.

Достаточно вспомнить, что препятствия, которые чинили китайские оккупационные власти в отношении проезда Уполномоченного НКИД РСФСР в Ургу, не оставляли никаких надежд на то, что О. И. Макстенек сможет приступить к исполнению своих служебных обязанностей. Более того, китайские власти если не сотрудничали, то, во всяком случае, «потакали» деятельности белогвардейцев и контрреволюции в Монголии, нанося прямой ущерб Центросоюзу 一 торговой и заготовительной организации Советской Сибири, осуществлявшей планирование и реализацию экономического сотрудничества Советской власти с Монголией. И только после того, как барон Р. Ф. Унгерн перешел границу Монголии, занял Ургу и освободил Богдо-гэгэна, китайские власти начали обращаться к О. И. Макстенеку как представителю молодого Советского государства.

Конечно, российский дипломат не сидел сложа руки: наряду с осуществлением оперативной деятельности по линии РКП(б) и Коминтерна, он проводил работу уполномоченного Наркомата иностранных дел РСФСР. Так, из справки О. И. Макстенека следует, что советско-китайские переговоры были начаты в сентябре 1920 г. Основным вопросом в них было противодействие китайских властей деятельности Центросоюза. Китайские солдаты устраивали настоящий произвол, творя грабежи и убийства служащих указанной организации. Оказавшись в сложной обстановке, китайские чиновники Маймачена потворствовали отрядам белогвардейцев, находившихся на монгольской территории. О. И. Макстенек в этой ситуации действовал четко и твердо, послав в Маймачен протесты против насилия, учиненного китайской военщиной, и против заигрывания китайских властей с белогвардейцами [Хишигт, Курас, Цыбенов 2020: 312]. 
После падения Урги началось паническое бегство китайских чиновников через территорию Дальневосточной республики (далее - ДВР). Благодаря решительным действиям О. И. Макстенека совместно с погранотрядами ДВР были блокированы все возможные пути нелегального транзита китайских граждан через территорию ДВР, оставив лишь один легальный путь, пролегавший по главной водной артерии региона - Селенге. Эта почти полная блокада передвижений «заставила китайские власти открыто обратиться за помощью к непризнанному ими советскому правительству» [Хишигт, Курас, Цыбенов 2020: 312].

Визы, необходимые для пересечения границы, находились в руках уполномоченного НКИД РСФСР, поэтому китайские власти были вынуждены выступить в неблаговидной для них роли просителей. В своем отчете О. И. Макстенек подчеркивал, что ему пришлось в сравнительно короткий период завизировать несколько тысяч паспортов граждан Китая. Много китайцев прибывало из Урги. Пересекали границу и купцы из Маймачена. Покидали территорию Внешней Монголии китайские чиновники, служившие в различных ведомствах. Крупные китайские фирмы направляли на имя О. И. Макстенека официальные обращения, пытаясь спасти имущество и жизни своих служащих.

По данным советского дипломата, всего поступило около 40 подобных обращений. Судя по содержанию, их можно разделить на два вида: 1) официальные обращения, где прямо указывается причина - бегство китайских чиновников, бросающих торговые фирмы на произвол судьбы, вынуждающее купцов просить советскую власть о покровительстве; 2) в некоторых обращениях отмечено противодействие китайского чиновника Нювибина работе таможни, что вызывало недовольство китайских купцов и, как следствие, их обращение за помощью к советскому дипломату [Хишигт, Курас, Цыбенов 2020: 313 ].

Часть китайских чиновников, очевидно, пыталась разрешить сложившуюся ситуацию военным путем. Известны их официальные просьбы о снабжении оружием и боеприпасами, вплоть до выдачи шести пушек.

15 февраля 1921 г. наместник в Монголии Чен-И обратился с официальным заявлением о выдаче визы. Он собирался выехать в Пекин, чтобы представить китайскому правительству доклад о ситуации во Внешней Монголии. И здесь у О. И. Макстенека проявился настоящий талант дипломата. Он поставил перед Чен-И ряд вопросов, связанных с действиями китайских и белогвардейских отрядов. Полуразложившиеся, больше напоминающие банды разбойников, чем регулярные части, эти отряды причиняли много бед местному населению. Более того, советский дипломат сознательно затягивал вопрос о выдаче виз. О. И. Макстенек понимал насущную необходимость ликвидации белогвардейцев, засевших в Монголии. В то же время ему было ясно, что китайские чиновники не имеют ни сил, ни возможностей для борьбы с ними. В этой связи отчетливо вырисовывалась роль Советской России в обеспечении мира в приграничной полосе, принятия советскими властями решительных мер для ликвидации скоплений вражеских сил на территории Монголии [Цыбенов, Курас 2021: 66]. То есть фактически Уполномоченный НКИД РСФСР начал дипломатическую проработку вопроса будущего ввода советских войск на территорию Монголии. Он справедливо полагал, что соглашение с китайскими властями обеспечит Советской России свободу действий на всей монгольской 


\section{Источниковедение}

территории. О. И. Макстенек фиксировал все действия китайских чиновников. Так, им отмечена передача полномочий наместника Монголии от Чен-И к Лию-Аню, состоявшаяся 22 февраля 1920 г. По мнению дипломата, тем самым Чен-И пытался отвести от себя личную ответственность за крах китайской власти во Внешней Монголии.

Соблюдая дипломатические правила, Чен-И направил официальное уведомление О. И. Макстенеку о передаче полномочий. Внезапно ставший наместником Монголии Лию-Ань попытался предпринять меры для урегулирования ситуации с белогвардейскими отрядами. 3 марта 1920 г. он направил официальное обращение советскому дипломату с просьбой о помощи. Суть обращения заключалась в возможности предоставления Советской России права на ввод войск во Внешнюю Монголию, причем советским войскам предоставлялась полная свобода действий в деле уничтожения белогвардейцев. В то же время в обращении Лию-Аня оговаривалось, что по окончании военных действий РСФСР должна вывести войска с монгольской территории, поскольку является дружественной державой по отношению к Китайской Республике [ЦА ВСМ. Ф. 495. Оп. 152. Д. 9. Л. 50-57].

Отчет О. И. Макстенека и его непосредственное участие в подготовке Монгольской революции в полной мере подтверждается сводками, телеграммами, оперативными донесениями, аналитическими записками, опубликованными в документальных изданиях [Монголия 2012; РМВС 2008].

Эти документы позволили нам изучить и оценить ту колоссальную организационную, политическую, экономическую и информационно-аналитическую работу, которую проделал Отто Иванович менее чем за год, по подготовке первого партийного съезда революционной монгольской партии, формированию ударных вооруженных сил монгольской революции, идейной подготовке монгольских революционеров, созданию условий для почти годичного пребывания «монгольской семерки» на территории ДВР и РСФСР и встрече с руководством ДВР, представителями Сиббюро Коминтерна и, наконец, с руководством Советского государства и РКП (б) во главе с В. И. Лениным. Именно поэтому монгольское руководство высоко оценило заслуги О. И. Макстенека перед МНР, наградив его высшим орденом страны — орденом Красного Знамени.

\section{Заключение}

Конечно, можно говорить о разнице происхождения И. Я. Коростовца и О. И. Макстенека, о колоссальной разнице в их образовании и социальном статусе, об огромной разнице в оценке их заслуг собственной страной. Но несомненно одно: они преданно и профессионально служили своему Отечеству и сделали очень много для формирования региональной системы международных отношений.

В период их деятельности межгосударственные отношения во Внутренней Азии достигли высокого уровня развития. При таком раскладе политическая организация под веянием революционных идей обретала большую устойчивость и жизнеспособность. Если И. Я. Коростовец создавал региональную систему отношений в Центральной Азии в рамках мировой системы международных отношений, то перед О. И. Макстенеком стояла более сложная задача. Дело в том, что внешняя политика нового государства — РСФСР с большим трудом 
вписывалась в традиционную систему международных отношений. Большое значение приобретала задача выстраивания новой внешней политики в отношении соседних стран, включая Китайскую Республику с формально входившей в ее состав Внешней Монголией. И в этой связи роль О. И. Макстенека значительно возрастает. А 100-летие российско-монгольских дипломатических отношений, которое отмечает в этом году общественность двух стран, — это событие, сопоставимое с юбилеем Монгольской революции 1921 г. Именно поэтому следует взглянуть на Монгольскую революцию 1921 г. через призму транснациональной истории народов монгольского мира в начале XX в., чтобы глубже понять наличие общих закономерностей и взаимосвязей с национально-освободительным движением на Востоке в целом и Октябрьской революцией 1917 г. в России [Курас 2016б].

\section{Источники}

ГА РФ - Государственный архив Российской Федерации.

ЦА ВСМ - Центральный архив внешних сношений Монголии.

\section{Sources}

Central Archive of Foreign Relations of Mongolia.

State Archive of the Russian Federation.

\section{Литература}

Бакич 2013 - Бакич О. История дневника И. Я. Коростовца // Монгол-Оросын 1912 оны гэрээ ба И. Я. Коростовец. Олон улсын эрдэм шинжилгээний бага хурлын материал (= Монгольско-русский договор 1912 года и И. Я. Коростовец. Мат-лы Междунар. науч. конф.). Улаанбаатар: Тод бичиг, 2013. С. 49-52.

Батсайхан 2013а - Батсайхан О. Монгол Оросын 1912 оны найрамдлын гэрээ ба И. Я. Коростовец // Монгол-Оросын 1912 оны гэрээ ба И. Я. Коростовец. Олон улсын эрдэм шинжилгээний бага хурлын материал (= Монгольско-русский договор о дружбе 1912 г. и И. Я. Коростовец // Монгольско-русский договор 1912 года и И. Я. Коростовец. Мат-лы Междунар. науч. конф.). Улаанбаатар: Тод бичиг, 2013. С. $143-155$.

Батсайхан 2013б - Батсайхан О. Уполномоченный императорского российского правительства в Монголии в августе 1912 - мае 1913 года Иван Яковлевич Коростовец // Россия и Монголия на рубеже XIX-XX веков: экономика, дипломатия, культура. Улан-Батор; Иркутск: БГУЭП, 2013. С. 161-170.

Батсайхан 2013в - Батсайхан $О$. Уполномоченный императорского российского правительства в Монголии в августе 1912 - мае 1913 г. Иван Яковлевич Коростовец // Вестник Бурятского научного центра Сибирского отделения Российской академии наук. 2013. № 4 (12). С. 77-87.

Батсайхан 2016 - Батсайхан О. Монголо-российский договор 1912 года и И. Я. Коростовец // Россия и Монголия: история, дипломатия, экономика, наука. Иркутск: БГУ; Улан-Батор: Арвай Бархан, 2016. С. 58-71.

Батсайхан 2021 - Батсайхан О. Монголо-русский договор 1912 г. как начало дипломатических отношений двух стран // Россия - Монголия: 100 лет вместе: мат-лы межд. науч. конф., посв. 100-летию установления российско-монгольских дипломатических отношений. Иркутск: ИГУ, 2021. С. 18-33.

Дацышен 2014 - Дацьишен В. Г. Очерки истории Монголии в XIX - первой четверти ХХ вв. М.: Директ-Медиа, 2014. 232 с. 


\section{Источниковедение}

Коростовец 2004 - Коростовец И. Я. От Чингисхана до Советской республики (Краткая история Монголии с особым учетом новейшего времени). Улан-Батор: Эмгэнт, 2004. $560 \mathrm{c}$.

Коростовец 2009 - Коростовеи И. Я. Девять месяцев в Монголии. Дневник русского уполномоченного в Монголии. Август 1912 - май 1913 г. / сост. О. Батсайхан. Улан-Батор: Эмгэнт, 2009. 440 с.

Курас 2016а - Курас Л. В. VIII Богдо-гэгэн Джэбдцзундамба-хутухта и Уполномоченный Российского императорского правительства в Монголии И. Я. Коростовец: роль личности в транснациональной истории монгольского мира в начале XX в. // Вестник Восточно-Сибирской государственной академии культуры и искусств. Улан-Удэ, 2016. № 2(11). С. 21-30.

Курас $2016 б$ - Курас Л. В. Транснациональная история монгольского мира в условиях революционного подъема: первая четверть XX века / рук. проекта, отв. ред. Б. В. Базаров, науч. ред. М. Н. Балдано. Иркутск: Оттиск, 2016. 252 с.

Курас 2011 - Курас Л. В. Геополитические амбиции атамана Семенова: попытка создания федеративного «Велико-монгольского государства» // Гуманитарный вектор. 2011. № 4 (28). С. 255-262.

Курас, Цыбенов 2013 - Курас Л. В., Цыбенов Б. Д. О роли российского дипломата И. Я. Коростовца в становлении Монгольского государства // Монгол-оросын 1912 оны гэрээ ба И. Я. Коростовец. Олон улсын эрдэм шинжилгээний бага хурлын материал (= Монгольско-русский договор 1912 года и И. Я. Коростовец. Мат-лы Междунар. науч. конф.). Улаанбаатар: Тод бичиг, 2013. С. 143-155.

Курас, Цыбенов 2020 - Курас Л. В., Цыбенов Б. Д. Отто Иванович Макстенек: год из жизни советского дипломата // Известия Иркутского государственного университета. Серия: История. 2020. Т. 32. С. 83-90.

Ленин 1969 - Ленин В. И. Полное собрание сочинений. 5-е изд. Т. 34. Июль-октябрь 1917. М.: Политиздат, 1969. С. 229-238.

Лиштованный 2013 - Лиштованный Е. И. Сибирь и Монголия в период деятельности И. Я. Коростовца // Монгол-оросын 1912 оны гэрээ ба И. Я. Коростовец. Олон улсын эрдэм шинжилгээний бага хурлын материал (= Монгольско-русский договор 1912 года и И. Я. Коростовец. Мат-лы Междунар. науч. конф.). Улаанбаатар: Тод бичиг, 2013. С. 74-82.

Монголия 2012 - Монголия в документах Коминтерна (1919-1934). Ч. 1. (1919-1929) / науч. ред. Б. В. Базаров. Улан-Удэ: БНЦ СО РАН, 2012. 527 с.

РМВС 2008 - Российско-монгольское военное сотрудничество (1911-1946). Сб. документов: в 2 ч. / отв. ред. В. П. Козлов, Д. Улзий-баатар. Ч. ІІ. М.; Улан-Удэ: Изд-во ВСГАКИ, 2008. 326 с.

Международные отношения 1933 - Международные отношения в эпоху империализма: документы из архивов царского и Временного правительств 1878-1917 гг.: Серия 3: 1914-1917. / подгот. к печ. А. С. Ерусалимский; при участии Б. Г. Вебера. М.; Л.: Гос. соц.-экон. изд-во, 1933. 559 с.

Нольде 1930 - Нольде Б. А. Далекое и близкое. Исторические очерки. Париж: Современные записки, 1930. 278 с.

Хишигт, Курас, Цыбенов 2020 - Хишигт Н., Курас Л. В., Цыбенов Б. Д. Отто Иванович Макстенек: у истоков монгольской революции 1921 года // Oriental Studies. 2020. T. 13. № 2. C. 305-317. DOI: 10.22162/2619-0990-2020-48-2-305-317

Цыбенов, Курас 2021 - Цыбенов Б. Д., Курас Л. В. «Как-то странно звучит слово «дипломатия» в устах коммуниста...»: о дипломатической деятельности уполномоченного НКИД РСФСР в Монголии О. И. Макстенека // Россия - Монголия: 100 лет вместе: мат-лы межд. науч. конф., посв. 100-летию установления российско-монгольских дипломатических отношений. Иркутск: ИГУ, 2021. С. 63-69. 


\section{References}

Bakich O. The diary of I. Ya. Korostovets: history reviewed. In: The 1912 Russo-Mongolian Treaty and I. Ya. Korostovets. Conference proceedings. Ulaanbaatar: Tod Bichig, 2013. Pp. 49-52. (In Russ.)

Batsaikhan O. Imperial Russia's Plenipotentiary in Mongolia Ivan Ya. Korostovets, August 1912 - May 1913. In: Russia and Mongolia at the Turn of the $20^{\text {th }}$ Century. Economy, Diplomacy, Culture. Ulan-Bator-Irkutsk: Baikal State University of Economics and Law, 2013. Pp. 161-170. (In Russ.)

Batsaikhan O. Imperial Russia's Plenipotentiary in Mongolia Ivan Ya. Korostovets, August 1912 - May 1913. Bulletin of the Buryat Scientific Center of SB RAS. 2013. No. 4 (12). Pp. 77-87. (In Russ.)

Batsaikhan O. The 1912 Russo-Mongolian Friendship Treaty and I. Ya. Korostovets. In: The 1912 Russo-Mongolian Treaty and I. Ya. Korostovets. Conference proceedings. Ulaanbaatar: Tod Bichig, 2013. Pp. 143-155. (In Russ.)

Batsaikhan O. The 1912 Russo-Mongolian Treaty and I. Ya. Korostovets. In: Russia and Mongolia. History, Diplomacy, Economy, Science. Irkutsk: Baikal State University; Ulaanbaatar: Arvay Barkhan, 2016. Pp. 58-71. (In Russ.)

Batsaikhan O. The 1912 Russo-Mongolian Treaty as a founding stone of mutual diplomatic relations. In: Russia - Mongolia. The Century of Friendship. Jubilee conference proceedings. Irkutsk: Irkutsk State University, 2021. Pp. 18-33. (In Russ.)

Bazarov B. V. (ed.) Mongolia in Documents of the Comintern, 1919-1934. Vol. 1: 1919-1929. Ulan-Ude: Buryat Scientific Center (Sib. Branch of RAS), 2012. 527 p. (In Russ.)

Datsyshen V. G. Mongolia, 1800s - 1920s: Historical Essays. Moscow: Direkt-Media, 2014. 232 p. (In Russ.)

Khishigt N., Kuras L. V., Tsybenov B. D. Otto I. Makstenek: at the origins of the Mongolian Revolution of 1921. Oriental Studies. 2020. Vol. 13. No. 2. Pp. 305-317. (In Russ.) DOI: 10.22162/2619-0990-2020-48-2-305-317

Korostovets I. Ya. From Genghis Khan to Soviet Republic: A Brief Chronicle of Mongolia, with Emphasis Laid on Contemporary History. Ulaanbaatar: Emgent, 2004. 560 p. (In Russ.)

Korostovets I. Ya. The Nine Months in Mongolia: Diary of Russia's Plenipotentiary to Mongolia, August 1912 - May 1913. O. Batsaikhan (comp.). Ulaanbaatar, 2009. 440 p. (In Russ.)

Kozlov V. P., Ulziy-baatar D. (eds.) Russian-Mongolian Military Cooperation, 1911-1946. Collected documents. In 2 vols. Vol. II. Moscow; Ulan-Ude: East-Siberian State Academy of Culture and Arts, 2008. 326 p. (In Russ.)

Kuras L. V. Ataman Semenov's geopolitical ambitions: an attempt of creating a federative 'Great Mongolian state'. Humanitarian Vector. 2011. No. 4 (28). Pp. 255-262. (In Russ.)

Kuras L. V. The $8^{\text {th }}$ Bogdo-Gegen Dzhebzundamba-Khutukhta and Plenipotentiary of the Imperial Russian Government in Mongolia I. Ya. Korostovets: the role of personality in the transnational history of the Mongolian world in the early $20^{\text {th }}$ century. Vestnik of East Siberian State Institute of Culture. 2016. No. 2 (11). Pp. 21-30. (In Russ.)

Kuras L. V. Transnational History of the Mongolian World in a Revolutionary Upsurge, 1900s - 1920s. B. Bazarov, M. Baldano (eds.). Irkutsk: Ottisk, 2016. 252 p. (In Russ.)

Kuras L. V., Tsybenov B. D. Otto Ivanovich Makstenek: year from life of the Soviet diplomat. The Bulletin of Irkutsk State University. Series 'History'. 2020. Vol. 32. Pp. 83-90. (In Russ.)

Kuras L. V., Tsybenov B. D. Russian diplomat I. Ya. Korostovets and his role in the shaping of Mongolia. In: The 1912 Russo-Mongolian Treaty and I. Ya. Korostovets. Conference proceedings. Ulaanbaatar: Tod Bichig, 2013. Pp. 143-155. (In Russ.)

Lenin V. I. Complete Works. $5^{\text {th }}$ ed. Vol. 34: July - October 1917. Moscow: Politizdat, 1969. Pp. 229-238. (In Russ.) 


\section{Источниковедение}

Lishtovanny E. I. Siberia and Mongolia in the era of I. Ya. Korostovets. In: The 1912 RussoMongolian Treaty and I. Ya. Korostovets. Conference proceedings. Ulaanbaatar: Tod Bichig, 2013. Pp. 74-82. (In Russ.)

Nolde B. A. The Far and the Near: Historical Essays. Paris: Contemporary Notes, 1930. 278 p. (In Russ.)

Tsybenov B. D., Kuras L. V. 'The word 'diplomacy' sounds weird when articulated by a Communist ...': Representative of RSFSR People's Commissariat of Foreign Affairs O. I. Makstenek and his diplomatic activities revisited. In: Russia-Mongolia. The Century of Friendship. Jubilee conference proceedings. Irkutsk: Irkutsk State University, 2021. Pp. 63-69. (In Russ.)

Yerusalimsky A. S., Veber B. G. (comps.) International Relations in the Era of Imperialism: Archival Documents of Imperial Russia's and Russian Provisional Governments, 18781917. Vol. 3: 1914-1917. Moscow; Leningrad: State Socioeconomic Book Publ., 1933. 559 p. (In Russ.) 